\title{
WHY SPEAK OF COMING (JOUISSANCE)?
}

You will find in this interview neither shrewd advice on how to have better orgasms (mieux jouir) nor despairing observations on a society that identifies sexual enjoyment ( jouissance) with greedy absorption in property and pleasure. Nor will you find any claim to prove wrong those who have already thought about the vices and virtues of sexual fulfillment (jouir).

In the following discussion, we were guided by a shared curiosity and an interest that was as expected as it was incongruous. Expected, because it is not taboo for contemporary thinking to discuss sexuality (at least since Freud and Bataille, among others), and yet incongruous, because sexual pleasure (jouissance) is not the dominant motive for these thoughts, which consider the sexual relationship (rapport) without taking into account the actual event that coming (jouir) is. Expected again, because the word "jouissance" has come to designate less 
sexual pleasure than the apex of what has long been called consummation, understood as an appropriation of benefits and satisfactions. But incongruous, precisely because it will not be a matter so much of using this word with the stigmatization of an economy or an ideology, but of reassessing (ressaisir) this experience that acts like an individual and collective engine, and that has been by turns-or even simultaneously-praised and condemned.

We think that jouissance presents itself as a major motive for reflection. Although it has not been present as such on the philosophical scene for some time, it was so once, very openly, with Plato, as it was afterwards in less visible but no less powerful ways in reflections about love, passion, and pleasure-philosophical, mystical, poetic, and literary writings, to which we grant much importance in this interview. We have also chosen to confront head-on the political stakes entrained by sexual pleasure (jouir), whenever it becomes the subject both of public claims (come without any restrictions!) and of public condemnations.

What does the word jouissance, sexual pleasure, mean, then, what do we understand by it, what is implied by it? Perhaps something unheard-of, even unhearable. That is not a reason not to try to understand it, and that is what has led us to have this interview.

Adèle Van Reeth and Jean-Luc Nancy

$\mathrm{x} \quad$ Why Speak of Coming (Jouissance)? 
COMING 
This page intentionally left blank 